Revista de Estudios Histórico-Jurídicos

[Sección historia del derecho indiano]

XLI (Valparaíso, Chile, 2019)

[pp. 265 - 288]

\title{
Bourbon-era Chile: Tomás Álvarez de Acevedo's VISITA AND LOCAL ENTANGLEMENTS
}

[Chile Borbónico: la Visita de Tomás Álvarez de Acevedo

y los vínculos locales]

\author{
JaVier Infante Martin* \\ Pontificia Universidad Católica de Chile
}

\begin{abstract}
RESUMEN
Este artículo se enfoca en el contexto social en el cual se desarrolló la Visita de Tomás Álvarez de Acevedo, los fuertes vínculos entre los magistrados locales y su consecuente resistencia ante los intentos reformistas que amenazaban con alterar su posición como autoridad local, así como su status social, y los obstáculos que el Visitador Regente enfrentó al llevar a cabo su tarea, mientras, al mismo tiempo, adaptó muchas de las nuevas políticas metropolitanas a las circunstancias locales, cumpliendo de esta manera su compromiso con la Corona.
\end{abstract}

Palabras Clave

Reformismo borbónico - Visita subdelegada - Derecho Indiano - Interés local - Chile colonial.

\section{Abstract}

This article seeks to show the social context within which Tomás Álvarez de Acevedo's visita was carried out, the strong ties between local magistrates and their subsequent resistance to any kind of reform that threatened to alter their position as local authorities as well as their economic and social status, and the obstacles the Visitador Regente faced in completing his task while, at the same time, adapting many of the new policies to the local circumstances, thereby achieving his commitment to the Spanish Crown.

$$
\begin{aligned}
& \text { KeYwords } \\
& \text { Pena de marca - Penas infamantes } \\
& \text { - Penas corporales - Infamia - De- } \\
& \text { calvatio. }
\end{aligned}
$$

ReCibido el 15 de mayo de 2018 y aCEPTADO el 15 de junio de 2018

\section{INTRODUCTION}

After the death of Fernando VI in 1759 and his absence from power during his last days as King of Spain, his half-brother, then Carlos VII of Naples, had to assume the Spanish throne. Even though the Bourbon reform process had

* Profesor de Historia del Derecho y de Derecho Comercial, Facultad de Derecho, Pontificia Universidad Católica de Chile. E-mail: jfinfante@uc.cl. 
already started years ago, it was not until the rise of Carlos III that a systematic and rigorous process of modernization took place throughout the Spanish Monarchy ${ }^{1}$, thus leading some historians to go so far as to qualify Carlos III as a "giant among Bourbon midgets"

The new King had little time to start this upgrade to his new colonies. After the invasion of Havana by the British, he implemented a series of measures focused on several aspects of the imperial administration, such as military restructuring, a new bureaucracy and, of course, a process of fiscal modernization. To achieve such an undertaking, Carlos III and his ministers used a very traditional institution: the visita ${ }^{3}$. Even though the visita was an old institution in Spain, Carlos III gave it a new function: it became not only an auditing tool, but an effective way to implement his new policies ${ }^{4}$. The first visita took place in Cuba just after Spain had traded the state of Florida for Havana following that city's wartime occupation by the British and was led by General Alejandro O'Reilly5. However, O'Reilly's mission was mainly a military one in order to set a new standard for the island's defense. This reflects how the war had an immediate impact in thrusting Bourbon reformism upon America $^{6}$. The first visita with a wider range of objectives took place in New Spain when José de Gálvez was appointed Visitador General, a post that lasted from 1765 to 1771 , when he was subsequently awarded a position on the Consejo de Indias ${ }^{8}$. In the Southern Hemisphere, the same visita took place, and it fell to José Antonio de Areche to act as Visitador General of Perú, Chile and Río de la Plata, having as its main sponsor the former Visitador General José de Gálvez, now Secretary for the Navy and the Indies. This visita to the southern portion of the Spanish empire began on September $5^{\text {th }}, 1777^{9}$ and, due to the

${ }^{1}$ STEIn, Barbara and STEIn, Stanley, The colonial heritage of Latin America. Essays on Economic Dependence in Perspective (USA, Oxford University Press, 1970), p. 99; HerR, Richard, The Eighteenth Century Revolution in Spain (USA, Princeton University Press, 1958), p. 235. For a different perspective on the character of Bourbon reform before Carlos III, see the new work of PERCE, Adrian J., The Origins of Bourbon Reform in Spanish South America, 1700-1763 (USA, Palgrave Macmillan, 2014).

${ }^{2}$ LyNCH, John, Bourbon Spain 1700-1808 (USA, Blackwell Publishers, 1993), p. 2.

${ }^{3}$ Burkholder, Mark and Chandler, D. S., From Impotence to Authority. The Spanish Crown and the American Audiencias, 1687-1808 (Columbia \& London, University of Missouri Press, 1977), p. 84.

${ }^{4}$ EsCoBEDO, Ronald, La Visita general durante el reinado de Carlos III. Estudio Comparativo, in Actas del VIII Congreso Internacional de Historia del Derecho Indiano (2000), p. 316.

${ }^{5}$ Góngora, Mario, Estudios sobre la Historia Colonial de Hispanoamérica (Santiago de Chile, Editorial Universitaria, 1998), p. 171.

${ }^{6}$ Stein, Barbara and SteIn, Stanley, Apogee of Empire. Spain and New Spain in the Age of Charles III. 1759-1789 (USA, John Hopkins University Press, 2003), p. 108.

${ }^{7}$ See Priesley, Herbert Ingram, José de Gálvez, Visitor General of New Spain (1765-1771) (USA, University of California, 1916).

${ }^{8}$ Brading, David, The First America. The Spanish Monarchy. Creole Patriots and the Liberal State 1492-1867 (UK, Cambridge University Press, 1991), p. 473.

${ }^{9}$ FISHER, John, Government and Society in Colonial Perú. The Intendant System 1784-1814 (UK, Bloomsbury, 2015), p. 12; SILVA, Fernando, La Visita de Areche en Chile y la Subdelegación del Regente Álvarez de Acevedo, in Historia, 6 (Chile, Pontificia Universidad Católica de Chile, 1967), p. 155. 
magnitude of the task, Areche was allowed to delegate his functions as Visitador General to visitadores subdelegados, namely Jorge Escobedo -in the Potosí Audiencia- and Tomás Álvarez de Acevedo in Chile ${ }^{10}$.

\section{Bourbon Reform Historiography}

In recent decades, a well-documented historiography has emerged on the issues of Bourbon reformism as well as political interpretations of the second half of XVIII century Spain ${ }^{11}$. This resource enables new researchers to approach the subject in a more comprehensive manner, as well as allowing them to go further in their conclusions, or to focus on more specific areas ${ }^{12}$.

There is a vast and rich literature concerning the Bourbon reform process in general, or approaching it as a political phenomenon in the larger contexts of the Spanish colonial empire. The fundamental work done by David Brading devotes several chapters to Bourbon reforms but within the context of a wider view of colonial America ${ }^{13}$. Richard Konetzke has also focused on the issue of Bourbon reformism in the general context of colonial history, presenting a vision of the different relations within colonial society and the metropolitan authorities ${ }^{14}$. Besides having more specific works on the Southern Hemisphere, John Lynch has published a remarkable book focused specifically on Bourbon-era Spain ${ }^{15}$.

Notwithstanding, most of the historiography focuses on political reforms in New Spain ${ }^{16}$, probably because of its undisputed importance during eighteenth-

${ }^{10}$ Silva, Fernando, La Visita de Areche en Chile, cit. (n. 9), p. 155.

${ }^{11}$ Herr, Richard, cit. (n. 1); Hargreaves-Mawdsley, W. N., Spain under the Bourbons, 1700-1833 (Macmillan, 1973); Burkholder, Mark and Chandler, D. S., cit. (n. 3); BurkHolder, Mark (ed.), Administrators of Empire (USA, Ashgate Publishing, 1998). For a more comprehensive and complete historiographical review, we recommend BARBIER, Jacques and Burkholder, Mark, Bourbon Colonial Period, in The History Teacher, 20/2 (Society for History Education, 1987), pp. 221-250, or a more recent work of PAQUETTE, Gabriel, The Dissolution of the Spanish Atlantic Monarchy, in The Historical Journal, 52/1 (Cambridge University Press, 2009), pp. 175-212.

${ }^{12}$ For example von Wobeser, Gisela, Dominación Colonial. La consolidación de vales reales, 1804-1812 (México, Universidad Nacional Autónoma de México, 2003). More recent works are the ones from Barbara Stein and Stanley Stein, Apogee of Empire, cit. (n. 6) and Edge of Crisis. War and Trade in the Spanish Atlantic, 1789-1808 (John Hopkins University Press, 2009). Also Kuethe, Allan and ANDrien, Kenneth, The Spanish Atlantic world in the Eighteenth Century. War and the Bourbon Reforms 1713-1796 (Cambridge University Press, 2014).

${ }^{13}$ BRADING, David, cit. (n. 8).

${ }^{14}$ KonetzKe, Richard, America Latina. La época colonial (España, Siglo XXI Editores, 2002).

${ }^{15}$ LYNCH, John, cit. (n. 2).

${ }^{16}$ See for example PIETSCHMAnN, Horst, Las reformas borbónicas y el sistema de intendencias en Nueva España. Un estudio político administrativo (México, Fondo de Cultura Económica, 1996), or from the same author: Revolución y Contrarrevolución en el México de las reformas borbónicas. Ideas protoliberales y liberales entre los burócratas ilustrados novohispanos (17801794), in Caravelle, 54, Presses Universitaires du Midi, pp. 21-35; or Consideraciones en torno al protoliberalismo, reformas borbónicas y revolución. La Nueva España en el último tercio del Siglo XVIII, in Historia Mexicana, 41 (1991), pp.167-205. Also ReES JonEs, Ricardo, El despotismo ilustrado y los intendentes de la Nueva España (México, Universidad Nacional Autónoma de 
century colonial history as well as the well-preserved and rich documentation from that period. The first m o d e r $\mathrm{n}$ visita took place in New Spain, and many of the later Bourbon reforms were implemented precisely due to the New Spain experience, such as the projection of the Ordenanza de Minería de Nueva España.

On the other hand, some authors have contributed more comprehensive studies on other areas of the Spanish colonial empire. John Lynch and his study of the intendant system in the Viceroyalty of La Plata ${ }^{17}$ and John Fisher's work on the Viceroyalty of Perú, among others, shed light on the implementation of reformism in South America. Other peripheral places, such as Central America or smaller regions like the Audiencia de Quito, are the subject of more recent studies ${ }^{18}$. In that sense, we think it may be a contribution to the field to focus on more peripheral regions of the Spanish colonial empire, establishing the necessary entanglements between these territories and the implementation of reformist policies, especially considering the economic boom that countries such as Chile experienced during and perhaps because of the reform process ${ }^{19}$.

For our specific approach, the literature on the Visita as an institution has caught the attention of historians for many years now. Herbert Priestley's classical work entitled José de Gálvez, Visitor General of New Spain (1765-1771) has been complemented with further research focused on the southern Viceroyalty. Kenneth Andrien has studied how this institution operated in Quito ${ }^{20}$ while Anthony McFarlane has devoted some pages to the Visita General in the Viceroyalty of New Granada ${ }^{21}$. Vicente Palacio has focused on Peru ${ }^{22}$, and/or the Alto Perú and Serena Fernández has produced probably the most exhaustive research regarding any of the Bourbon Visitas, providing a detailed and thorough monography on all the aspects of the delegated Visita carried out by Jorge Escobedo, and his

México, 1979); García, Clara (coord.), Las Reformas Borbónicas 1750-1808 (México, Fondo de Cultura Económica, 2010).

${ }^{17}$ LYNCH, John, Administración colonial española 1782-1810. El sistema de intendencias en el Virreinato del Río de la Plata (Buenos Aires, Editorial Universitaria de Buenos Aires, 1962). The implementation of the Intendant System has been studied from a general perspective in the now classic book of FISHER, Lillien Estelle, The Intendant System in Spanish America (California University Press, 1929). Also see NAVARro, Luis, Las Intendencias en Indias (Sevilla, Escuela de Estudios Hispanoamericanos, 1959).

${ }^{18}$ AndrIEn, Kenneth, The Kingdom of Quito, 1690-1830 (UK, Cambridge University Press, 1995) or Dym, Jordana and Belaubre, Christophe, Politics, Economy, and Society in Bourbon Central America, 1759-1821 (USA, University Press of Colorado, 2007). For the Chilean case among the peripheries of the colonial empire, see BARBIER, Jacques, Reform and Politics in Bourbon Chile 1755-1796 (University of Ottawa Press, 1980).

${ }^{19}$ Kuethe, Allan and Andrien, Kenneth, cit. (n. 12), p. 19.

${ }^{20}$ ANDrIEn, Kenneth, The Politics of Reform in Spain's Atlantic Empire during the Late Bourbon Period: The Visita of José García de León y Pizarro in Quito, in Journal of Latin American Studies, 41/4 (Cambridge University Press, 2009), pp. 637-662.

${ }^{21}$ MCFarlane, Anthony, Colombia before Independence. Economy, society and politics under Bourbon rule (United Kingdom, Cambridge University Press, 1993).

${ }^{22}$ Palacio, Vicente, Areche y Guirior. Observaciones sobre el fracaso de una visita al Perú, in Anuario de Estudios Americanos, 3 (Sevilla, 1946). 
subsequent ascension to the position of Visitador General, after Areche's fall ${ }^{23}$. In Chile, Fernando Silva studied the Visita Subdelegada with a special focus on matters of public finances, customs, tobacco and mining ${ }^{24}$.

\section{THE VISITA SUBDELEGADA}

There is a sizeable body of literature on the subject of the Visita Indiana. The consensus is that, considering the vast timeline of the Spanish empire as well as the different character of both ruling dynasties, the content and spirit of the institution changed, having a distinctive seal during Bourbon rule. Regarding this matter, Ernesto Schafer recalls the main visitas during Habsburg rule as being inefficient vis-à-vis their professed purpose: “[...] So it was not possible to just transplant the proven system of the Metropolis to the far colonies, with some hope of success [...] so many times, the mission was entrusted to some men who barely had an idea of the true situation in the colonies, and they could only judge it by applying the points of view in the existing literature" 25 . To the unfitness of the visitadores, Sánchez Bella has added other factors: the colonial local awareness and thus the distrust towards the visitadores, the high cost involved in every visit, very often long in duration but short on results ${ }^{26}$.

In contrast, the visita had renewed use during Bourbon rule. As Céspedes del Castillo has noted, during the reign of Charles III, "it was actually an instrument to implement his wide political, territorial and economic reforms in the Indies"27. It stopped being just an inspection mechanism and was used as a tool for implementing new policies. Consequently, opposed to former visits, newly appointed visitadores forged a new relationship with the Spanish monarchy: they had its absolute trust and political support when faced with local political obstacles ${ }^{28}$. It was in this context that the first major visit took place in the Viceroyalty of New Spain, then the richest part of the Spanish colonial dominions. The person chosen to do the job was José de Gálvez.

After distinguished service as a clerk in the Spanish Imperial Court, lawyer José de Gálvez was appointed Inspector of New Spain. His main sponsor was a member of the Treasury Council (Consejo de Hacienda), the attorney Francisco

${ }^{23}$ Fernández, Serena, Presencia de Jaén en América: La Visita General de Jorge Escobedo y Alarcón al Virreinato del Perú en el Siglo XVIII (1782-1788) (Jaén, Diputación provincial de Jaén, 1991).

${ }^{24}$ Silva, Fernando, La Visita de Areche en Chile, cit. (n. 9).

${ }^{25}$ SCHAFER, Ernesto, El Consejo Real y Supremo de las Indias: su historia, organización y labor administrativa hasta la terminación de la casa de Austria (Sevilla, Escuela de Estudios HispanoAmericanos, 1947), p. 156.

${ }^{26}$ Sánchez Bella, Ismael, Eficacia de la visita en Indias, in Anuario de Historia del Derecho Español, 50 (Madrid, 1980), p. 388.

${ }^{27}$ Céspedes del Castillo, Guillermo, La visita como institución indiana, in Anuario de Estudios Americanos, 3 (Sevilla, 1946), p. 1003.

${ }^{28}$ Escobedo, Ronald, cit. (n. 4), p. 318; also Burkholder, Mark and Chandler, D. S., cit. (n. 3), p. 84 . 
Carrasco who had previously presented a plan for improving colonial fiscal affairs ${ }^{29}$. Perhaps his nomination was due to a small report he had written, entitled Discurso y reflexiones de un vasallo sobre la decadencia de nuestras Indias Españolas ${ }^{30}$, in which Gálvez detailed his ideas for improving colonial trade, as well as a complete restructuring of public finances. Most of Gálvez's Proyecto is focused on substituting the fleet and galleon system (sistema de flotas y galeones) for a system of free vessels (navios sueltos) as well as substituting Cadiz's mercantile monopoly, advocating for a freer trading system with New Spain -which is the main concern of this work- and thus to all the colonized areas. Regarding this last point, Gálvez did not hesitate to argue that "[...] one can hardly recognize the Spain that possesses the rich empires of America [...]" due to the foreign ownership of vessels and trade offices under Spain's aegis which existed in Cádiz.

This Proyecto was in line with the general tendencies of that period among Spanish bureaucrats and, as in other cases, it served its purpose while opening a wider door for its author, winning him an appointment as Visitador General of New Spain, a position which he held rather successfully between 1765 and 1771. After that, he was rewarded with a position on the Council of the Indies in 1775 and, in 1776, he was appointed Secretary for the Indies. As is evident, his vast experience and knowledge of colonial affairs were exceptional, and his disposition to introduce reform was in total accordance with the enlightened government of Charles III. It is not surprising then that, for a better understanding and management of his new duties, he had in mind carrying out new visitas to other territories not included in his own post as visitador ${ }^{31}$.

Consequently, Gálvez quickly appointed one of his former subordinates -José Antonio de Areche- during his Visita of New Spain, and entrusted him with a similar task in the southern regions. Gálvez's trust in Areche was so complete that, when he took the oath of office in Lima amidst the opposition of then Viceroy Guirior, the latter was quickly removed from office and replaced by Chilean Governor Agustín de Jáuregui. Areche was clearly standing on very firm ground for his commission. His jurisdiction included not only the territories making up the Viceroyalty - territories directly governed by the Viceroy- but also provinces located far apart, such as Charcas and the Captaincy General of Chile (Capitanía General de Chile). The former was entrusted to Jorge de Escobedo, minister of the Audiencia de Charcas, whilst the second fell to the newly appointed Regente of the Chilean Court, Tomás Álvarez de Acevedo.

This magistracy -the Regente- had been recently created and introduced in the colonies. The Instrucción de Regentes was promulgated in 1776, driven by

\footnotetext{
${ }^{29}$ SánCHEZ Bella, Ismael, Las reformas en Indias del Secretario de Estado José de Gálvez (17761787), in BARrios, Feliciano (coord.), Derecho y administración pública en las Indias Hispánicas: Actas del XII Congreso Internacional de Historia del Derecho Indiano (Spain, Universidad de Castilla-La Mancha, 2001), p. 1518.

${ }^{30}$ Colom, Francisco, Discurso y reflexiones de un vasallo sobre la decadencia de nuestras Indias Españolas. Extractos, in Araucaria. Revista Iberoamericana de Filosofía, Politica y Humanidades, 5/9 (Universidad de Sevilla, 2003).

${ }^{31}$ Escobedo, Ronald, cit. (n. 4), p. 316.
} 
Gálvez himself. It altered the hierarchy of both the Audiencia-placing the Oidor Decano's attributions in the hands of the Regente- and the colonial government, establishing a set of powers and honors for the new authority, as well as depriving the Governor of his judiciary role in the administration of the Audiencia, although still keeping him as President of the court. The importance of this new post hinged on the new role or relevance bestowed by the Crown upon the colonial courts, which, while important, were in some ways decadent when Bourbon rule started. For instance, the Chilean Audiencia was completely purged in $1776^{32}$ after a series of disagreements between its ministers and the newly appointed Contador Mayor Silvestre García. The power and influence of the court ministers, as well as their identification with local interests which was prohibited and frowned upon by the Crown, made it necessary for the metropolis to set a new standard for American court members in order to avoid making the same mistake. Thus, the establishment of a proprietary, fulltime administrator of the Audiencia was completely aligned with Gálvez's idea of hierarchy and metropolitan control. And who better positioned to be named as delegate for the Visita subdelegada in the eyes of the Crown than Gálvez himself. On April $7^{\text {th }}, 1777$, the Visitador Areche received a decree stating that, provided he had not already designated a delegate from among his own trusted circle, the appointment had to then fall on Álvarez de Acevedo. Accordingly, Areche drew up a precise set of instructions for the Chilean Regente, dated October $17^{\text {th }}$ of that same year.

These instructions to Álvarez de Acevedo were very thorough, consisting of 47 precise paragraphs that left very little room for maneuvering on the part of the Subdelegado ${ }^{33}$. Such constraints on the Visitador General were unacceptable from Álvarez de Acevedo's point of view, and he tried to avoid them accordingly, although without any success ${ }^{34}$. Even though his position as Subdelegado was weak, he still had broad attributions due to his appointment. Since the main purpose of the visita was to audit public finances: "[...] as is precise to, in proportion of the huge increase in the expenses that the Royal Treasure suffers in the vast extension of these dominions for its Government and Defense, to promote all means apparently leading to promote, as much as possible, the real Values and Royal Rights, avoiding in this way his beloved vassals the assessment of new taxes [... "35. Within this general mandate to inspect the Royal Finances, the instructions were very specific

${ }^{32}$ Barbier, Jacques, "Elite and Cadres in Bourbon Chile", in Burkholder, Mark (ed.), cit. (n. 11), p. 107.

${ }^{33}$ For example, in the last article of the Instructions, Areche ordered Álvarez de Acevedo to inform him about any aspect of importance which could cause "considerable inconvenience". Article 47, Instructions from José Antonio de Areche to Tomás Alvarez de Acevedo, April 7th, 1777, Archivo General de Indias, Chile, 410.

${ }^{34} \mathrm{He}$ wrote to Gálvez asking about the scope of his attributions: whether he was a mere extension of the Inspector General or had a degree of independence in his tasks. By a new Royal Order, he was confirmed as being dependent on Areche in Perú. Silva, Fernando, La Visita de Areche en Chile, cit. (n. 9), p. 157.

${ }^{35}$ Instructions from José Antonio de Areche to Tomás Álvarez de Acevedo, April 7th, 1777, Archivo General de Indias, Chile, 10 sheets. 
in the different aspects that were to comprise auditing the Contaduria Mayor ${ }^{36}$ in every file and annotation, the composition of its personnel ${ }^{37}$, inspecting and controlling the accounts carried by Corregidore ${ }^{38}$-including a special mission to check on the possibility of ending the sales monopoly held by these corregidores over the Indian population under their jurisdiction, as well as the possibility of establishing a higher salary for them to replace that controversial benefit-, updating and sorting past or pending accounts ${ }^{39}$, assets and liabilities ${ }^{40}$, and so on. But his attributions were not only oriented towards auditing but he was also to play a more active role: there were some measures he had to enforce to modify and modernize the Royal administration. For instance, if there were still some trade branches in the hands of private administrators - such as tobacco- or some taxes like the value-added tax - then those activities had to return to the Royal jurisdiction ${ }^{41}$. This last point is a very good example of the spirit in which this Visita was carried out: it was not a mere routine overhaul, but a tool for updating Royal control over many aspects that were in the hands of local elites, and thus the possible reaction from the local population had to be taken into account as a factor for this task's failure or success. And those interests, despite this Visita and subsequent reforms, were kept aligned with the Royal aims. As Barbier has noted, "Unlike Peru, Chile remained quiet during the Visita-largely because the government remained sensitive to local desires" 42 . This alleged peace in the territory is not a minor factor -even when considering the peripheral character of Chile's location and relatively minor status- but rather a reflection of the Visitador-Regente's moderate character.

\section{The INSTRUCCIÓN DE VISITA AND PUBLIC FINANCES}

As Professor Álvaro Jara has pointed out, Chilean finances were -to an important degree- dependent on those of the Viceroyalty of Perú. The resulting deficit, although relevant for the colonial treasury, was aggravated during the first half of the XVIII century when the extraction of minerals in Perú decreased, while increasing in New Spain ${ }^{43}$. This phenomenon alone explains the motives behind Bourbon reformism. It was not a master plan designed to refound the colonial political structure, nor was it a complete vision of all the required measures to increase revenue and control over the American territories in a more efficient manner. On the contrary, Bourbon reformism was a long process, motivated or informed to some degree by the philosophy of the prevailing air du temps,

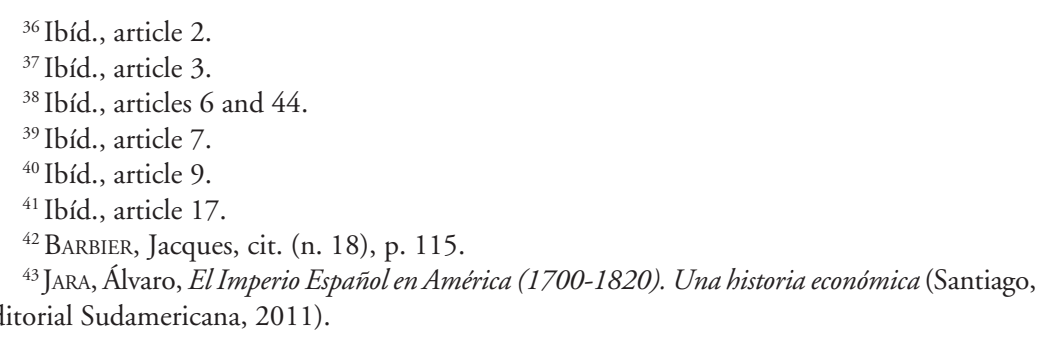


embraced by some and rejected by others, as many political and economic vested interests were destined to collide with each other in a long and difficult process. Thus, the Visita was a perfect instrument for gathering some degree of knowledge that might be useful in the implementation of new policies. Of course, since not all the visitas took place at the same time, nor did all of them have the same scope of tasks, many of the projects observed as desirable by Metropolitan authorities were implemented before the Visita took place -with the Visitador General acting as a mere observer or corrector if needed (e.g. the Contaduría Mayor de Cuentas in Chile)- or, while the Visita was underway, having the Inspector General act as a comptroller for the Crown even above the local traditional authorities. When we refer to public finances, the Visitador General fulfilled this latter role. His mission was not to be a mere observer of how the tax process and Royal Treasury were operating, but to perform as an active magistrate in the projected modifications ordered by the Crown, or by making his own suggestions in situ regarding improvements in the pursuit of better results ${ }^{44}$.

As stated above, when Álvarez de Acevedo arrived in Chile, his duties as Visitador General were combined with those of Regente of the local court. However, historians -as well as his contemporaries ${ }^{45}$ - agree that, despite the enormous scope of his responsibilities, he measured up to the task $\mathrm{k}^{46}$.

His instructions were written by Visitador General Areche and were dated October $17^{\text {th }}, 1777$, in Lima ${ }^{47}$. In these instructions, the spirit and nature of the Visita subdelegada were explained in detail, while at the same time summarized in three short lines: "[...] subdelegando, como subdelego en dicho Señor Regente don Tomás Álvarez de Acevedo todas mis facultades en lo concerniente a la Visita de la Real Hacienda en el Reino de Chile, se servirá dicho Señor Ministro tener a la vista los articulos siguientes [...]"48. As one may see, the primary purpose of the Visita was to inspect the public finances. However, the magnitude of the task, as well as the attributions delegated by Areche, were specifically detailed in 47 articles.

For a complete understanding of his Instructions, we may classify the articles into groups, according to the nature of the department Álvarez de Acevedo was supposed to inspect. The first group would be related to the Visita to the Tribunal

${ }^{44}$ Silva, Fernando, La Visita de Areche en Chile, cit. (n. 9), p. 158.

${ }^{45}$ Carvallo, Vicente, Descripción Histórico-geográfica del Reino de Chile (Santiago, Imprenta de La Estrella de Chile, 1875), included in Colección de Historiadores de Chile y Documentos relativos a la Historia Nacional (Heretofore referred to as $\mathrm{CHCH}$ ), Vol. IX. José Antonio Pérez García (1726-1814) voiced the same opinion: “[...] This new job [interim President] was not a heavy load for this president in the perfect fulfillment of his three other posts. He attended proceedings in the Royal Court without fail. At the door of his house, twice a week, as Regent he would dispatch verbal rulings. As Visitador General for the Kingdom, he knew how to carry out his duties. And he, as Captain General, secured the important Valdivia region for the Crown [...]”. Pérez García, José Antonio, Historia General, Natural, Militar, Civily Sagrada del Reino de Chile (Santiago, Instituto de Chile, 2013), p. 835.

${ }^{46}$ Silva, Fernando, La Visita de Areche en Chile, cit. (n. 9), p. 156.

${ }^{47}$ Instrucciones dadas por José Antonio de Areche a Tomás Álvarez de Acevedo, Archivo General de Indias, Chile, 418, 45 sheets.

${ }^{48}$ Archivo General de Indias, Chile, 418. 
Mayor de Cuentas and the Real Hacienda, inspecting every branch of the public finances -from tobacco to Corregidores- (articles 2-16), and having a decisive inspecting nature in order to craft an exhaustive and thorough inventory. A second group would be related to fiscal modifications needed for a better administration of those same royal resources, where we may see as a central proposal the idea of ending the leasing of some branches, such as the arrendamiento de tabacos, and its replacement by a Crown Monopoly -which happened after some local turmoil- (articles 17-20). A third group was related to the administration of public resources, as well as to the income and expenses of the Royal Treasury (articles 21-24). Then came instructions for inspecting the territory's mining situation and the Casa de Monedas or Mint (articles 25-26) as well as inspecting the collection of special taxes such as Lanzas, Media Anata or Cruzada (articles 27-28), Tobacco (articles 29-31), and smaller taxes such as those levied on Gunpowder, Cards, Lottery, Tithes, Indians, Ecclesiastical Rights (articles 32-37). It also included attributions to inspect and report on the mines located throughout the territory (articles 38-39) and, finally, some instructions regarding improvements in the government (such as exploring the convenience of installing the Intendant system in Chile), as well as some legal attributions granted to the Visitador over all departments abovementioned regarding the Royal finances. While granting Álvarez de Acevedo broad powers, the true spirit behind these instructions was to merely delegate. Thus, Areche expressed himself not in a loose way but rather kept to himself his final judgment over any proposal Álvarez de Acevedo might propose and, in some cases, did not delegate any attribution at all but reserved it for himself. A case in point was the Visita to the local Audiencia. Areche had received separate instructions for auditing the Audiencia in Lima ${ }^{49}$ in accordance with Gálvez's expectations for purging American courts of local entanglements. However, Areche only delegated his duties related to public finances, leaving the auditing of the Chilean Audiencia aside. This was probably not due to a lack of confidence in his delegate, but a reflection of an unnecessary measure: Álvarez de Acevedo had already been appointed Regent of the Chilean court and, thus, he had sweeping powers for auditing and governing the Audiencia without further specification.

At any rate, once settled in his post as Visitador, Álvarez de Acevedo's main concern was the scope of his duties ${ }^{50}$. We must not forget that, even though he was an "accessory" to Areche, he was also incumbent in the Chilean Regency of the Audiencia. Therefore, he found himself in the awkward position of being auxiliary in some matters, and a definitive authority in others. That may explain his constant friction with Areche regarding his attributions and prerogatives. This obviously provoked a tense dispute between Areche and Álvarez de Avecedo regarding the reach of the Visita subdelegada. For Areche, Álvarez de Acevedo

\footnotetext{
${ }^{49}$ PalaCio, Vicente, Areche y Guirior: Observaciones sobre el fracaso de una visita al Perú, in Anuario de Estudios Americanos, 3/1 (Sevilla, 1946), pp. 279-280.

${ }^{50}$ At the end of the Instructions, Areche was very specific: "[when facing any crucial decision] [...] me lo representará con individualidad, para en su vista tomar la resolución que corresponda [...]". Archivo General de Indias, Chile, 418.
} 
was a mere deputy in the context of the Visita General51 ${ }^{51}$ while, from Álvarez de Acevedo's perspective, he was autonomous and almost independent in his task. Perhaps he may have been inclined to think that way since his appointment did not come from Areche, but directly from José de Gálvez. He may have also felt that the trust placed in him by being appointed Visitador subdelegado while he was also the administrative head of the local Audiencia -and thus the second ranked officer in the territory after the Governor- implied somehow that there was a direct line between him and the Secretario de Indias. It is therefore not uncommon for Álvarez de Acevedo, as Visitador General, to reach out directly to Gálvez, bypassing Areche in Perú. Even though Areche was, after a while, going to run into trouble with Viceroy Guirier, and was to be deposed and subject to trial -Juicio de residencia- after his return to Spain, we must keep in mind that his appointment as Visitador General was due precisely to his close relationship with Gálvez, whom he had helped during his Visita to New Spain ${ }^{52}$. It should not then be a surprise that, in the conflicts Areche had with his delegate, Gálvez normally ruled in Álvarez de Acevedo's favor, even though the latter was also in a position of confidence and restructuring as Regent.

Álvarez de Acevedo learned all that the hard way. He asked Minister Gálvez about the true scope of his attributions and whether he was expected to act independently or as a mere subordinate to Areche. Gálvez was confirmed the latter, probably because the Visita General was just starting, and it was not convenient to undermine Areche's position ${ }^{53}$ which was already facing difficulties due to the initially soft and later hard opposition from Viceroy Guirior in favor of one of his own delegates, whether Regent or not. However, Álvarez de Acevedo's position in the Chilean court gave him an excellent excuse to avoid his dependence on Areche since, as Regent, he undoubtedly had access to the Via Reservada, allowing him to contact Secretary Gálvez by his own right. A good example of this, is that even in his reports to Areche, Álvarez de Acevedo identified himself as "Regent of the Royal Appeals Court of Santiago" (Regente de la Real Audiencia de Santiago), and not as Visitador subdelegado which was his specific title with regard to the Visita.

This atmosphere of mistrust between Areche and Álvarez de Acevedo may have conditioned the success of the Visita. For Areche, his frequent conflicts with other colonial magistrates such as Viceroy Guirior and his successor Jáuregui, Oidores in the Audiencia de Lima, or his delegate in Chile may have been an obstacle too difficult to overcome, no matter how well-established his connections in Madrid were. As Palacio has noted, "[Gálvez] had raised Areche up, but did not have the necessary strength to avoid his fall [...]"54. For Álvarez de Acevedo, the lack of

${ }^{51}$ SILVA, Fernando, Reformismo y revolución: modificaciones administrativas y tributarias en Chile, 1770-1808, in La América Hispana en los albores de la Emancipación. Noveno Congreso de Academias Iberoamericanas de la Historia (Spain, Real Academia de la Historia [and others], 2005), p. 256.

${ }^{52}$ Campbell, Leon, A Colonial Establishment: Creole Domination of the Audiencia of Lima during the Late Eighteenth Century, in The Hispanic American Historical Review, 2/1 (1972), p. 7.

${ }^{53}$ Silva, Fernando, La Visita de Areche en Chile, cit. (n. 9), p. 157.

${ }^{54}$ Palacio, Vicente, cit. (n. 22), p. 387. 
support from his superior may have been a defining factor in the outcome of his efforts $^{55}$. This defect translated into a deficit of government officers available to help Álvarez de Acevedo in his endeavor to transform Chilean finances.

Since the energy and diligence of the Regent were beyond question, and even though his role as Visitador General was not as successful as his role of Regent, we may be inclined to think that the difference was due precisely to the precariousness of his resources. But another reason may be found in the close ties the Regent was able to build during his time as Visitador General, and the tact he displayed while performing the difficult role of auditor. Some examples may be found in some of his proceedings, such as his inspection of the tobacco monopoly (Renta de Tabacos) or Customs (Aduanas).

\section{The Visita, Royal Bureau, Offices and local entanglements}

As we have already described, the nature of Álvarez de Acevedo's endeavor was mainly related to auditing Chilean finances and, given the mercantile system of the time, also auditing the boards in charge of some public monopolies, such as Tobacco or Customs, or private farming areas such as tax collection or mining. In every area, an Office -Administración- was normally the highest ranking authority for problem resolution, accounting and administration -like the Junta o Administración de Tabacos or the Administración de Aduanas-, each one with its own officers such as an administrator, accountant and treasurer, besides others of lower rank. Each one also had its own patrimony consisting of warehouses, office buildings and others that belonged indirectly to the Crown. By the time of the Visita, other private tax farming offices of importance were already in the hands of the Crown, such as the Mint. Of course, these administrations -whether public or private-were under the financial and accounting jurisdiction of the Contaduria Mayor del Reino, established precisely to consolidate and control Chilean finances ${ }^{56}$.

When the Regent began his Visita, he showed an incredible display of energy by sending orders to each one of these Bureau Administrations stating that they should send him the final accounting reports for fiscal years in order to inspect them. He also issued instructions to the accountant of the Visita, Juan Navarro, so he could begin auditing the accounts when they arrived ${ }^{57}$. The trouble for Álvarez de Acevedo started here.

His accountant, Juan Navarro, refused to take on his assigned work, arguing that it would not be of any help since he had already been transferred to a different

\footnotetext{
${ }^{55}$ Silva, Fernando, La Visita de Areche en Chile, cit. (n. 9), pp. 157; 189-188.

${ }^{56}$ Even though the Contaduria or Tribunal de Cuentas was very successful under its first Contador Mayor, Silvestre García, it began to operate poorly after his death, probably due to the weaker skills of his successor, Contador Interino Gregorio González Blanco, and the even worse attitude shown by the next incumbent, José Tomás Echevers. See SiLVA, Fernando, $L a$ Contaduría Mayor de Cuentas del Reino de Chile, in Historia de las Instituciones Políticas y Sociales, 2 (Santiago, 1967), pp. 103-179.

${ }^{57}$ Alvarez de Acevedo to Navarro, March 13 $3^{\text {th }}, 1778$, Archivo General de Indias, Chile, 328.
} 
position ${ }^{58}$. Thus, only having begun, the Visita lost one of its key officers. The Visitador General was already running short on personnel. But, being a diligent officer and after insisting that Navarro had to assume his duties and accusing him of having a defiant attitude, he eventually appointed the Director of Chilean Customs as interim accountant ${ }^{59}$. The choice would prove to be wrong in the long term but had immediate results for the Visita, as Pedregal acted with diligence in every task Álvarez de Acevedo ordered him to carry out.

Leaving aside the problems regarding the lack of staff, the Regente-Visitador General continued with his task addressing the problem in a direct manner, dealing personally with accounting problems and visiting the different offices to inspect their operations, accounting, and general state. In that context, he turned to the administrator $^{60}$-Francisco Antonio Abaria- and the accountant ${ }^{61}$ of the Tobacco Monopoly, ordering them to be responsible for the office's books until a new accountant arrived to take over. His idea worked because the Customs Administrator and Visita acting accountant responded with a detailed, 77-point report explaining the status of Chilean finances and bureaus, including their personnel, buildings and methods. In Pedregal's report, there were some suggestions for the Regent, such as the importance of trading with tobacco of a higher quality, better service for consumers and avoiding potential social discontent, "[...] as was already seen last year in 1776 and repeatedly reported in public 'rags', the news of which could have reached the Crown had it not been for the damage control measures taken by the Supreme Government $[\ldots]$ ".62. He also suggested it was

58 “[...] En el día me hallo provisto en el empleo de Director de la Real Aduana del Reino de Nueva España, que Su Majestad se ha dignado conferirme, cuya real orden me impele a trasladarme sin pérdida de tiempo a servir mi nuevo destino [...]". Navarro to Álvarez de Acevedo, March $13^{\text {th }}, 1778$, Archivo General de Indias, Chile, 328.

${ }^{59}$ The accusations against Navarro were strong. Álvarez de Acevedo berated him for either "[...] falta de inteligencia en las materias de que trata [...]" or "[...] poco celo por el aumento de la Real Hacienda [...]”. The decree finally stated that, in Navarro's absence, "[...] Pásese este expediente al Administrador General de Real Aduana [...] para que informe lo que se le ofreciere sobre su contenido [...]". Alvarez de Acevedo to Pedregal, January $28^{\text {th }}, 1780$. Archivo General de Indias, Chile, 328. Despite the date of this appointment, apparently the relationship between Álvarez de Acevedo and Pedregal started long before. Why the Regent had such an affinity with Pedregal is a mystery, but the answer may be found in the strong social skills that characterized the Regent, and thus his efforts to make the appropriate connections in order to fulfill his task in a successful manner. As an example of how fruitful such alliances could be, one might add that Pedregal had proven to be a useful partner for the higher magistracies of the land since he was in close collaboration with the purged ministers of the Audiencia-1776- and had even won the hand of Oidor Concha's daughter in marriage, probably as a reward for his cooperation with the Court. BARBIER, Jacques, cit. (n. 18), p. 103.

${ }^{60}$ Alvarez de Acevedo to Administrador General de la Real Renta de Tabacos, March $15^{\text {th}}$, 1778. Archivo General de Indias, Chile, 328.

${ }^{61}$ Alvarez de Acevedo to Abaria, September 9 ${ }^{\text {th }}$, 1778. Archivo General de Indias, Chile, 328.

${ }^{62}$ This is a good example of Ácevedo's diplomacy. In 1776, after an attempt by interim Contador Mayor Gregorio González Blanco to expand the Royal revenue by increasing taxes -among other measures- an episode ensued that some historians have dubbed "the Mutiny of the Excise Tax" (Motin de las Alcabalas) that eventually frustrated the intended reform. Pedregal to Alvarez de Acevedo, Point 6, April 6 ${ }^{\text {th }}$, 1780. AGI, Chile, 328. Also see Barbier, 
wise to appoint a delegate in Lima to look out for the Chilean Tobacco Bureau's interests, as well as build more appropriate warehouses for the tobacco stock in the port of Valparaíso, claiming that the existing ones were in poor conditions and were not appropriate for tobacco storage due to the moisture, bad smells and lack of stock rotation. But his main suggestion was contained in the second part of his report regarding the the Tobacco Bureau's accountability. Here, Pedregal spoke of the delay which characterized the register of revenue and expenses in the respective books, a practice that was common among Bureau employees and was sanctioned by the Administrator. And what was worse, in the case of the books for the year 1779, the same Administrator had in his books "[...] incomplete reports and some entirely blank $[\ldots . .]^{\prime 63}$. For that reason, Pedregal suggested that Álvarez de Acevedo impose the implementation of a standard form printed in Lima in 1770 to standardize the accounting books with those of the Administración General de Tabacos in Lima ${ }^{64}$. This solution was also suggested by Areche, and the Regent ordered its implementation that same year ${ }^{65}$. Those standard forms were sent to every corregimiento and military Governor -such as Valdivia, Valparaíso and Juan Fernández Islands- so they too could inform on the tobacco stocks available in their jurisdictions. In this manner, the Visitador General could rely on a comprehensive inventory showing the total amount and quality of the tobacco. Of course, some Corregidores took their time in answering, and Álvarez de Acevedo had to insist on more than one occasion. Finally, by May of 1780, some of them had sent their reports, allowing the Visita to continue.

Since the Visitador General and his main aide Pedregal were not precisely on friendly terms with the Contador Mayor, Echevers, and the Administrator of Tobacco, Abaria, the Visita was repeatedly stalled by constant conflicts between them. It is only natural that in a country where the King's officers were used to a high degree of discretion regarding their behavior, an auditor was not a welcome visitor. So, when the Regente-Visitador General faced such open opposition in his jurisdiction, he reached out to Minister Gálvez who supported him and finally gave him absolute power over all the tobacco issues ${ }^{66}$. With this vote of confi-

Jacques, cit. (n. 18) Chapter V; SILVA, Fernando, El motín de las alcabalas en 1776, in Boletín de la Academia Chilena de la Historia, 86 (Santiago de Chile, 1972), pp. 13-37; Villalobos, Sergio, El Descontento contra la política económica de los Borbones en Chile, in Revista de Estudios Americanos, 78-79 (Sevilla, 1958), pp. 135-143; CARMAGNANI, Marcelo, La oposición a los tributos en la segunda mitad del Siglo XVIII, in Revista Chilena de Historia y Geografia, 129 (Santiago de Chile, 1961), pp. 158-195.

${ }^{63}$ Pedregal to Álvarez de Acevedo, Point 40, April 6 ${ }^{\text {th }}, 1780$. Archivo General de Indias, Chile, 328.

${ }^{64}$ Pedregal to Álvarez de Acevedo, Point 45, April 6 ${ }^{\text {th }}$, 1780. Archivo General de Indias, Chile, 328.

${ }^{65}$ September 25 ${ }^{\text {th }}, 1780$ (Auto signed by Álvarez de Acevedo). Archivo General de Indias, Chile, 328.

66 “[...] y quiere su Majestad que Vuestra Señoría [Álvarez de Acevedo...] avoque así el conocimiento de todos los puntos, que en virtud de dichas órdenes empezó a promover Echevers, y todos los demás asuntos y negocios de este Ramo [...]”. Real Orden, Madrid, April 1st, 1779. Chile, Archivo General de Indias, 328; “Tiene el Rey resuelto que el Regente de esa Audiencia don Tomás Álvarez de Acevedo, de acuerdo con el Visitador General don José Antonio de 
dence, Álvarez proceeded to close down the Tobacco Bureau (Junta de Tabacos) and remove every member ${ }^{67}$. This point shows the support that Gálvez-and only circumstantially Areche- showed Álvarez de Acevedo in the way he conducted the Visita. However, the suppression of the Tobacco Bureau and the exclusion of Contador Mayor Echevers in the control over the Tobacco business deepened the breach between him and the Visita. This is probably why Echevers channeled his energies and disconformity to oppose the Visita's Achilles' heel: Customs Administrator and Acting Accountant for the Visita, Ramón del Pedregal. Echevers accused him of misappropriating Royal Revenues and other irregularities, such as colluding with high Court members to avoid the payment of some taxes. The situation, even though exaggerated by Echevers, proved to be true and, of course, left a small stain on the Visita. Nevertheless, Pedregal's situation was to be jeopardized not only by local enemies, but also by the disposition of Visitador General Areche. In early February of 1781, Pedro Dionisio Gálvez, who until that day had served as General Accountant for the Visita General in Perú, arrived in Santiago and immediately notified Álvarez de Acevedo of two different orders. The first one involved the Contaduria of the Visita subdelegada: from that day, he was to be recognized as the incumbent, thus removing Pedregal as from his interim post. The second order was to be a source of greater conflict: at the same time, Pedro Gálvez was to replace Pedregal as head of the Customs Bureau. The first order was confirmed by the King ${ }^{68}$, while the second one came from Areche, signed by his General Sub-delegate, José Ramos de Figueroa. The Regente-Visitador immediately recognized Pedro Gálvez as accountant for the Visita ${ }^{69}$ but, since in the second order the appointment of Pedro Gálvez as administrator had been granted based on the allegedly prior resignation submitted by Pedregal, the Regente-Visitador informed his aide about his replacement and, seeing his surprise, gave him two days to appeal that resolution. Pedregal did so and expressed his surprise arguing that he had never resigned from his position as Royal Administrator, and had only presented a request for a possible position as second Contador Mayor. He even attached documents proving his good credentials as Administrator, his confirmation by the $\mathrm{Crown}^{70}$, as well as favorable references from Chilean President Jauregui or the Inspector General himself. Thus, he requested the suspension of this resolution until it was clarified by the Crown. Álvarez de Acevedo suspended the ruling handed down by Ramos de

Areche, sea quien por ahora, única y privativamente, entienda en todos los asuntos y negocios gubernativos, contenciosos y de Real Hacienda, y de cualquiera otra clase, que sean de la Renta de Tabacos de ese Reino [...]". Minister Gálvez to Álvarez de Acevedo, April 1st, 1779. AN, Capitanía General, 718, p. 32.

${ }^{67}$ The file is in Chile, Archivo General de Indias, 328, Document N ${ }^{\circ} 8$.

${ }^{68}$ Appointment bestowed in San Idelfonso, August 20 $0^{\text {th }}, 1778$. Archivo General de Indias, Chile, 328; AN, Capitanía General, Vol. 728, p. 170.

${ }^{69}$ Álvarez de Acevedo, Decree, April 2nd, 1781. Archivo General de Indias, Chile, 328.

${ }^{70}$ Appointment bestowed in San Idelfonso, September 20th, 1780. Archivo General de Indias, Chile, 328. 
Figueroa $^{71}$ and informed Areche of his decision ${ }^{72}$. Even before the file containing the documents that supported Álvarez de Acevedo's ruling arrived, Areche sent a new order, dated May $21^{\text {st }}$ in Cuzco, urging his delegate in very severe terms to comply with his previous order or face the wrath of Areche's accusations before the Crown. In his communication, Areche accused his delegate of having a disarrayed office - descuadernada-, as well as having personal motivations for disobeying his wishes. When Álvarez de Acevedo received this communication, he noted that it was sent without having the documents and reports that informed the file he had sent Areche, and was thus mistaken in its conclusions. He therefore insisted on keeping Pedregal's replacement suspended until a well-grounded decision had been taken ${ }^{73}$. He also informed President Jáuregui who presented the problem to the Real Acuerdo, supporting the Regent's decision ${ }^{74}$, as well as Minister Gálvez of the partial suspension of Areche's decision. Pedro Gálvez was immediately admitted as Accountant for the local Visita, even arguing that it was most inconvenient to change such an important Administrator at that point in time. This was an express reference to the Tupac Amaru rebellion in Perú -whereby Areche emerged highly compromised-suggesting that it might arouse suspicion among the native-born Chileans (naturales) and make them think that "attributions were being altered or changed to their detriment ..."75, thus covering his back from every possible angle. His strategy showed effectiveness since his rulings were confirmed by the Crown, and Ramón del Pedregal was confirmed as administrator of the Customs Bureau ${ }^{76}$.

However, Álvarez de Acevedo's triumph came with a Trojan horse. His -until then- right-hand man kept his post, but the new incumbent accountant lost a highly attractive appointment as King's Officer that would benefit him with a second salary besides the one as accountant for the Visita. Therefore, it was almost to be expected that Pedro Gálvez was not going to be the most cooperative person

${ }^{71}$ April 7th, 1781. AGI, Chile, 418.

${ }^{72}$ May 4th, 1781. AGI, Chile, 418.

${ }^{73}$ Álvarez de Acevedo to José de Gálvez, October 31st, 1781. Archivo General de Indias, Chile, 418. Álvarez de Acevedo informed Areche in a very intelligent and well-presented letter, pleading that "[...] Bien quisiera poder contestar a dicha [yours] carta de un modo que quedase V.S. satisfecho de mi subordinación a sus preceptos; pero habiendo reflexionado el asunto, y formado dictamen en conciencia de que pendiente la resolución de dicho informe o consulta de 4 de mayo, y subsistiendo en el mismo estado las razones y consideraciones legales en que se fundó dicha mi providencia de 7 de abril, no me es facultativo revocarla ni alterarla en manera alguna, hasta que así lo mande V. S. o su Subdelegado en vista de los enunciados Autos e Informe [...]". Archivo General de Indias Chile, 418.

${ }^{74}$ President Jáuregui to José de Gálvez, December $3^{\text {rd }}$, 1781. Archivo General de Indias, Chile, 418.

${ }^{75}$ Alvarez de Acevedo to José de Gálvez, June 1st, 1781. Archivo General de Indias, Chile, 418.

76 "Apruébese a Acevedo su providencia previniéndole que continúe Pedregal hasta otra de esta vía reservada y el Contador de Visita en su comisión [...]". November $7^{\text {th }}, 1781$. Archivo General de Indias, Chile, 328; "Apruébase al Presidente y al Regente sus determinaciones, avisando de ello al Visitador, y previniendo a este que tome el debido conocimiento para resolver el asunto de que dará cuenta a Su Majestad". May 20 $0^{\text {th }}, 1782$. Archivo General de Indias, Chile, 328; Benavides to Gálvez, January 31st, 1783. Archivo General de Indias, Chile, 192. 
with Álvarez de Acevedo ${ }^{77}$. Nor was he going to be on good terms with Ramón del Pedregal who, as we have seen before, had already made some enemies while acting as interim accountant for the Visita (such as the Head of the Tobacco Bureau, Mr. Abaria). To this end, Pedro Gálvez quickly started accusing Pedregal of some irregularities involving the Customs Bureau books, in the same way Contador Mayor Echevers had tried not long before ${ }^{78}$.

Apparently, when Álvarez de Acevedo was granted the exclusive jurisdiction over the entire Tobacco Administration, the Contador Mayor felt that his integrity was being questioned and he himself relegated to being a mere spectator during the Visita of the Real Hacienda which, by definition, was his exclusive realm. Consequently, he revived the accusations leveled against Ramón del Pedregal regarding irregularities in the way the books were kept in his office ${ }^{79}$, based on the

${ }^{77}$ Pedro Gálvez wrote to Minister Gálvez using very harsh terms, and showing his discontent on his suspension as Customs Administrator. On his reception by Álvarez de Acevedo, he ensured that he was welcomed by these words: "Aquí estamos todos en paz, y no hay necesidad de invertirla". Regarding the rest of the officers and ministers, he stated: "Son hombres tan inicuos, que fundan la duración de su pernicioso Sistema en el retiro de Vuestra Excelencia del despacho y gobierno de estas Américas, y en la suspensión de la Visita, o muerte del Jefe tan dignamente encargado de ella", pointing to them as "delincuentes [...] formados sin honra y nutridos por la malicia [...] cobardes [que] sacrifican el servicio al ídolo de su conservación [...]”. Pedro Gálvez to José de Gálvez, September 6th, 1781. Archivo General de Indias, Chile, 418.

${ }^{78}$ The animosity between Contador Mayor Echevers and Customs Administrator Pedregal went back a few years before when, in 1777, the former accused the latter-using the vía reservadaof marrying the daughter of High Court Judge (Oidor) Melchor de Santiago Concha [note 54] and thus exposing himself to entanglements. By becoming kin to her extended family, Echevers accused Pedregal of not collecting some taxes from some of their friends and protectors. The tone of the letter speaks for itself: "[...] el matrimonio que contrajo el Administrador de Alcabalas de este Reino don Ramón del Pedregal, y si es con hermana o parienta del Oidor don Melchor de Santiago Concha, si tiene conexión con los otros oidores o la familia de don José Perfecto de Salas; si se halla adherido a estos ministros y disimula el cobro de derechos de los frutos de sus haciendas, y negociaciones, como se practicó el reconocimiento de los equipajes de Salas cuando llegó de Lima [...]". Echevers to Gálvez, January 29" 417. The charges and kinship relations are explained in a more detailed manner in another letter, this time from Pedro Fermín de Necochea to Minister Arriaga, dated November $29^{\text {th }}$, 1775: "Usted sabe que el difunto [First Contador Mayor Silvestre García] dejó como Segundo albacea a D. Ramón del Pedregal, Administrador General de Reales Derechos de Alcabala y Almojarifazgo, que ha contraído matrimonio con doña Antonia Cerda, Hermana de D. Nicolás Cerda, yerno del señor don [Oidor] José Clemente Traslaviña, cuya hermana fue casada con hermano del expresado señor Concha. De esta suerte se ha adquirido la protección de estos Ministros, la del señor Capitán General, y la del señor fiscal don José Perfecto de Salas, de cuya casa es inseparable, viniendo así la Real Administración al principio de inconveniente y sujeta a la voz y autoridad de dichos señores [...]”. Letter cited in Donoso, Ricardo, Un letrado del Siglo XVIII, el doctor José Perfecto de Salas (Buenos Aires, Universidad de Buenos Aires, 1963), p. 457.

${ }^{79}$ The accusations against Pedregal were not new and he had faced them before. Being the first Customs Administrator in Chile, a task previously developed by an ad hoc Junta composed of high ranking ministers and officers, he became involved with the local aristocracy through business and family ties. Thus, he faced the open accusations from Interim Contador Mayor Gregorio González Blanco who lacked the social skills and affinities of his predecessor. Even worse, precisely for being associated with the Chilean political elite-some Audiencia Ministers and the Salas Family [Fiscal José Perfecto and his son Procurador del Cabildo Manuel de Salas] 
Customs accounting books he had under his custody (books dating up to 1778). He managed to accuse Pedregal of embezzling 233,924 pesos out of the Royal Treasury and Pedregal was to be charged for their restitution. After Álvarez de Acevedo's intervention, the amount was finally reduced but Pederegal's credibility was severely affected, and all of his efforts were then focused on defending himself. He asked Governor Benavides to grant him permission to travel to Lima for better results against the accusations. Thus, for his mission as Visitador, Álvarez lost a close ally as well as a competent officer with sharp accounting skills.

However, the removal of Pedregal was not by any means decisive for the completion of Álvarez de Acevedo's task. During the same time period when these episodes took place, Visitador General Areche deemed fit to appoint a special Visitador for the Chilean Tobacco Bureau and thus commissioned the New Spain Director of Tobaccos, José de la Riva Agüero. This magistrate received wide attributions from Areche but, in the end, did not exercise them save for a few cases. As Silva has noted, Álvarez de Acevedo's skilled diplomacy prevented any conflict between them and, when Areche's rising star finally declined and he was removed from office, Riva Agüero also gave up his duties ${ }^{80}$ without major achievements.

\section{Final considerations: Álvarez de Acevedo and the political ESTABLISHMENT}

As we have seen, the Visita -and thus the Visitador-were seen by some as an opportunity for political fame through official communications. Others, especially those in middle-ranking positions, were more skeptical about the true motives for the inspection which could eventually end in charges being made if irregularities

were among the most vocal opponents to reforms proposed by González in 1776 (see note 57)- Pedregal faced the accusations of being involved in irregular activities with them and that translated into tax exemptions in their favor. The most famous episode involves the return of José Perfecto de Salas to Chile -where he was incumbent fiscal- after serving as legal advisor (Asesor Letrado) to Viceroy Amat, former Governor of Chile. Apparently, Pedregal chose to look another way while Salas sent his personal luggage from Lima and in which some contraband may have been found. Interim Contador Mayor González accused Pedregal of exempting Salas from paying 4,400 pesos between 1773 and 1776 [Donoso, Ricardo, cit. (n. 78), p. 453]. Finally, in a Royal Order signed by Gálvez, Álvarez de Acevedo was instructed to compare the inventory reported by Gonzalez as interim Contador Mayor with the one submitted by Ramón del Pedregal as Customs Administrator (Royal Order handed down in San Idelfonso, September $20^{\text {th }}, 1780$ ). The accountant for the Visita performed the comparison which showed a lower amount (May $\left.11^{\text {th }}, 1781\right)$. After hearing out Echevers and Pedregal for one more time, Álvarez de Acevedo asked for the informe fiscal. It arrived on January $21^{\text {st }}, 1782$, condemning interim Contador Mayor González for his responsibility in not keeping due diligence in his office, as well as for defaming Pedregal for spurious reasons concerns. The fiscal-Fernando Márquez de la Platawas very severe in his accusation, charging González with expressions such as "voluntariedad", "calumnioso", "infidelidad y oscuro procedimiento", and "[faltar] al sagrado Respeto procurando captar el Real Ánimo a la sombra especiosa de un fingido celo para inclinarlo a una Resolución contraria a su Natural Rectitud [...]". He therefore recommended that the difference be paid not by Pedregal, nor the Salas estate, but by González Blanco. Archivo General de Indias, Chile, 328.

${ }^{80}$ Silva, Fernando, La Visita de Areche en Chile, cit. (n. 9), p. 170. 
were discovered. And even when we see that both assumptions were right to some degree, the general reaction to the Visita was of mistrust towards the Visitador, and nonconformity with being audited by some magistrate who did not even live in the area. After all, before the Visita started, local officers acted autonomously to a large extent, thanks to a corrosive policy of alliances and entanglements that served local interests first above those of the Spanish Crown. The removal of Audiencia Ministers in Chile took place precisely for this reason, and so too did a General Inspection in Perú and with regional ramifications. But, besides highranking magistrates such as Audiencia Ministers and Royal Administrators, there were other officers who were also affected by the Visita: provincial administrators. When Álvarez de Acevedo arrived in Chile, there were 19 different territories in the country, 16 of which reported directly to the Chilean Governor, and were thus included in the Visita. The others reported to the Viceroyalty of Perú (Chiloé Island) or Presidios -fortifications- (Juan Fernández Islands and Valdivia). Therefore, the Regente-Visitador had 16 territories to inspect and audit, 15 corregimientos and a Governor who reported directly to him (the port of Valparaíso).

In September of 1778, Álvarez de Acevedo sent 16 questionnaires to each and every one of those territories, asking for a complete description of their respective lands, including their economy, demography and settlements, public property, mining, urban and rural properties, as well as Royal Officers and their salaries ${ }^{81}$. As Solano has pointed out, it is truly remarkable that all of the recipients answered the call, some with diligence, and some almost two years after receiving the questionnaires ${ }^{82}$. Using those documents, Álvarez de Acevedo wrote a report entitled Noticias Generales del Reino de Chile where one may appreciate the commitment and diligence with which the Visitador took on his task, describing every aspect of the different Chilean provinces in careful detail. This report was included among the 201 files that Álvarez de Acevedo sent to Gálvez in $1781^{83}$. These documents must have been very useful for what would later be probably the main achievement of the Visita Subdelegada in Chile: the implementation of the Intendant System in 1786, one year after the closing of the Visita General in Perú, by then in the hands of Escobedo ${ }^{84}$.

\footnotetext{
${ }^{81}$ All these documents form a file entitled Relaciones Económicas del Reino de Chile. We have not consulted these documents directly, but through their published version. As their publisher has said, these documents were separated from the rest of the files documenting the Chilean Visita, and were found not in Chile nor in Sevilla but in the Bauzá Collection belonging to the British Library, London. Solano, Francisco, Relaciones económicas del Reino de Chile (1780) (Madrid, Consejo Superior de Investigaciones Científicas, 1994).

${ }^{82}$ Solano, Francisco, cit. (n. 81), p. 26.

${ }^{83}$ Ibíd., p. 27.

${ }^{84}$ The implementation of the Intendant System in Chile has been partially studied by María Teresa Cobos and Ricardo Rees Jones, while it also has been mentioned in books regarding other regions or as a general perspective. CoBOs, María Teresa, El régimen de intendencias en el Reino de Chile. Fase de implantación 1786-1787, in Revista de Historia del Derecho, 7 (Santiago, Universidad de Chile, 1978), pp. 85-106; Coвos, María Teresa, Notas para el estudio de las intendencias en el Chile Indiano, in Revista de Estudios Histórico-Jurídicos, 11 (Valparaíso, Universidad Católica de Valparaíso, 1986), pp. 109-141; CoBos, María Teresa, La división
} 
As we have seen, the Visita subdelegada came in a decisive moment for the Spanish Crown. The Bourbon Reform was at its height and the momentum provided by metropolitan authorities gave it a further boost. However, the appointed magistrate, also Regent of the Chilean Court, had to face open opposition to his attributions by both local authorities and his superior, Visitador General Areche, for whom he was only a delegate and nothing more.

But, leaving aside the opposition he faced, the Visita carried out by Acevedo may be considered a success: he managed to audit all the major finance boards in the Chilean territory, while at the same time keeping the peace and even gaining some supporters and customers. While Areche had to face the open revolt of Tupac Amaru, Álvarez de Acevedo managed to govern his public agenda in a climate of peace and tranquility. He even built a strong reputation for himself among the members of Chilean society and even ended up marrying the daughter of an Oidor. The Crown recognized his efforts by appointing him Adviser (Consejero) on the Council of the Indies, as well as distinguishing him with the Orden de Carlos $I I I$, created to reward distinguished civil servants. His ties with local society were probably not diminished by distance since he kept contact with Chileans traveling to Spain, and his son was later appointed minister for the Chilean Audiencia, a position he never held due to the War of Independence.

Perhaps his success is to be found precisely there: unlike Areche who promptly became an enemy in the eyes of Viceroy Guirior among other high magistrates in Perú, Álvarez de Acevedo carried out his duties in a more diplomatic way, avoiding open opposition unless it was inevitable. Instead of opposing Audiencia ministers, he acted like one and, aside from one or two small clashes regarding honors and protocol, he was also recognized by his colleagues in court. He protected his aides, and became involved in a sincere campaign to promote progress in a territory where he was called to act only as a delegate auditor.

Finally, it is important to consider that, although unrelated to Álvarez de Acevedo, the Visita is another example of Bourbon reformism's paradoxical nature, i.e. while pursuing a new standard of efficiency in the colonial administration as its primary objective, by implementing new institutions such as the Visita, the Regency or the Intendant System among others, this process inspired local aspirations for a more autonomous government by increasing local awareness and political experience in public matters.

politico administrativa de Chile, 1541-1811 (Valparaíso, Universidad Católica de Valparaíso, 1989); Rees Jones, Ricardo, La aplicación de la Ordenanza de Intendentes de Buenos Aires en el Reino de Chile, in Revista de Historia del Derecho, 19 (Buenos Aires, instituto de Investigaciones en Historia del Derecho, 1991), pp. 327-347; Navarro, Luis, Intendencias en Indias (Sevilla, Consejo Superior de Investigaciones Científicas, 1959); FISHER, Lillian Estelle, The Intendant System in Spanish America (New York, Gordian Press, 1969). 


\section{FUENTES CITADAS}

Andrien, Kenneth, The Politics of Reform in Spain's Atlantic Empire during the Late Bourbon Period: The Visita of José García de León y Pizarro in Quito, in Journal of Latin American Studies, 41/4 (Cambridge University Press, 2009).

- The Kingdom of Quito, 1690-1830 (UK, Cambridge University Press, 1995).

BARbier, Jacques, Reform and Politics in Bourbon Chile 1755-1796 (University of Ottawa Press, 1980).

Barbier, Jacques and Burkholder, Mark, Bourbon Colonial Period, in The History Teacher, 20/2 (Society for History Education, 1987).

BArbier, Jacques, Elite and Cadres in Bourbon Chile, in Burkholder Mark (ed.) Administrators of Empire (Great Britain, Ashgate, 1998).

Brading, David, The First America. The Spanish Monarchy. Creole Patriots and the Liberal State 1492-1867 (UK, Cabridge University Press, 1991).

BurKHOlder, Mark (ed.), Administrators of Empire (USA, Ashgate Publishing, 1998).

Burkholder, Mark and Chandler, D. S., From Impotence to Authority. The Spanish Crown and the American Audiencias, 1687-1808 (Columbia \& London, University of Missouri Press, 1977).

Carmagnani, Marcelo, La oposición a los tributos en la segunda mitad del Siglo XVIII, in Revista Chilena de Historia y Geografia, 129 (Santiago de Chile, 1961).

Carvallo, Vicente, Descripción Histórico-geográfica del Reino de Chile (Santiago, Imprenta de La Estrella de Chile, 1875), included in Colección de Historiadores de Chile y Documentos relativos a la Historia Nacional (Heretofore referred to as $\mathrm{CHCH})$, Vol. IX.

Céspedes del CASTILlo, Guillermo, La visita como institución indiana, in Anuario de Estudios Americanos, 3 (Sevilla, 1946).

Cовоs, María Teresa, El régimen de intendencias en el Reino de Chile. Fase de implantación 1786-1787, in Revista de Historia del Derecho, 7 (Santiago, Universidad de Chile, 1978).

- Notas para el estudio de las intendencias en el Chile Indiano, in Revista de Estudios Histórico-Jurídicos, 11 (Valparaíso, Universidad Católica de Valparaíso, 1986).

- La división politico administrativa de Chile, 1541-1811 (Valparaíso, Universidad Católica de Valparaíso, 1989).

Colom, Francisco, Discurso y reflexiones de un vasallo sobre la decadencia de nuestras Indias Españolas. Extractos, in Araucaria. Revista Iberoamericana de Filosofía, Politica y Humanidades, 5/9 (Universidad de Sevilla, 2003).

Donoso, Ricardo, Un letrado del Siglo XVIII, el doctor José Perfecto de Salas (Buenos Aires, Universidad de Buenos Aires, 1963).

Dym, Jordana and Belaubre, Christophe, Politics, Economy, and Society in Bourbon Central America, 1759-1821 (USA, University Press of Colorado, 2007).

Escobedo, Ronald, La Visita general durante el reinado de Carlos III. Estudio Comparativo, in Actas del VIII Congreso Internacional de Historia del Derecho Indiano (2000).

Fernández, Serena, Presencia de Jaén en América: La Visita General de Jorge Escobedo y Alarcón al Virreinato del Perú en el Siglo XVIII (1782-1788) (Jaén, Diputación provincial de Jaén, 1991).

FISHER, Lillien Estelle, The Intendant System in Spanish America (California University Press, 1929). 
FiSHER, John, Government and Society in Colonial Perú. The Intendant System 17841814 (UK, Bloomsbury, 2015).

García, Clara (coord.), Las Reformas Borbónicas 1750-1808 (México, Fondo de Cultura Económica, 2010).

Góngora, Mario, Estudios sobre la Historia Colonial de Hispanoamérica (Santiago de Chile, Editorial Universitaria, 1998).

Hargreaves-Mawdsley, W. N., Spain under the Bourbons, 1700-1833 (Macmillan, 1973).

Herr, Richard, The Eighteenth Century Revolution in Spain (USA, Princeton University Press, 1958).

Instructions from José Antonio de Areche to Tomás Álvarez de Acevedo, April 7th, 1777, Archivo General de Indias, Chile.

JarA, Álvaro, El Imperio Español en América (1700-1820). Una historia económica (Santiago, Editorial Sudamericana, 2011).

Jones, Ricardo, El despotismo ilustrado y los intendentes de la Nueva España (México, Universidad Nacional Autónoma de México, 1979).

KonetZKe, Richard, America Latina. La época colonial (España, Siglo XXI Editores, 2002).

Kuethe, Allan and Andrien, Kenneth, The Spanish Atlantic world in the Eighteenth Century. War and the Bourbon Reforms 1713-1796 (Cambridge University Press, 2014).

LYNCH, John, Administración colonial española 1782-1810. El sistema de intendencias en el Virreinato del Río de la Plata (Buenos Aires, Editorial Universitaria de Buenos Aires, 1962).

- Bourbon Spain 1700-1808, (USA, Blackwell Publishers, 1993).

McFarlane, Anthony, Colombia before Independence. Economy, society and politics under Bourbon rule (United Kingdom, Cambridge University Press, 1993).

NAVArro, Luis, Las Intendencias en Indias (Sevilla, Escuela de Estudios Hispanoamericanos, 1959).

Palacio, Vicente, Areche y Guirior. Observaciones sobre el fracaso de una visita al Perú, in Anuario de Estudios Americanos, 3 (Sevilla, 1946).

Paquette, Gabriel, The Dissolution of the Spanish Atlantic Monarchy, in The Historical Journal, 52/1 (Cambridge University Press, 2009).

Pérez García, José Antonio, Historia General, Natural, Militar, Civil y Sagrada del Reino de Chile (Santiago, Instituto de Chile, 2013).

Pietschmann, Horst, Consideraciones en torno al protoliberalismo, reformas borbónicas y revolución. La Nueva España en el último tercio del Siglo XVIII, in Historia Mexicana, 41 (1991).

- Revolución y Contrarrevolución en el México de las reformas borbónicas. Ideas protoliberales y liberales entre los burócratas ilustrados novohispanos (1780-1794), in Caravelle, 54.

- Las reformas borbónicas y el sistema de intendencias en Nueva España. Un estudio político administrativo (México, Fondo de Cultura Económica, 1996).

Priesley, Herbert Ingram, José de Gálvez, Visitor General of New Spain (1765-1771) (USA, University of California, 1916).

Rees Jones, Ricardo, La aplicación de la Ordenanza de Intendentes de Buenos Aires en el Reino de Chile, in Revista de Historia del Derecho, 19 (Buenos Aires, instituto de Investigaciones en Historia del Derecho, 1991). 
SÁnchez Bella, Ismael, Eficacia de la visita en Indias, in Anuario de Historia del Derecho Español, 50 (Madrid, 1980).

- Las reformas en Indias del Secretario de Estado José de Gálvez (1776-1787), in BARRIOS, Feliciano, Derecho y administración pública en las Indias Hispánicas: Actas del XII Congreso Internacional de Historia del Derecho Indiano (Spain, Universidad de Castilla-La Mancha, 2001).

SCHAFER, Ernesto, El Consejo Real y Supremo de las Indias: su historia, organización y labor administrativa hasta la terminación de la casa de Austria (Sevilla, Escuela de Estudios Hispano-Americanos, 1947).

Silva, Fernando, La Contaduría Mayor de Cuentas del Reino de Chile, in Historia de las Instituciones Politicas y Sociales, 2 (Santiago, 1967).

- La Visita de Areche en Chile y la Subdelegación del Regente Álvarez de Acevedo, in Historia, 6 (Chile, Pontificia Universidad Católica de Chile, 1967).

- Reformismo y revolución: modificaciones administrativas y tributarias en Chile, 17701808, in La América Hispana en los albores de la Emancipación. Noveno Congreso de Academias Iberoamericanas de la Historia (Spain, Real Academia de la Historia [and others], 2005).

Solano, Francisco, Relaciones económicas del Reino de Chile (1780) (Madrid, Consejo Superior de Investigaciones Científicas, 1994).

Stein, Barbara and SteIn, Stanley, Apogee of Empire. Spain and New Spain in the Age of Charles III. 1759-1789 (USA, John Hopkins University Press, 2003).

- The colonial heritage of Latin America. Essays on Economic Dependence in Perspective, (USA, Oxford University Press, 1970).

Villalobos, Sergio, El descontento contra la politica económica de los Borbones en Chile, in Revista de Estudios Americanos, 78-79 (Sevilla, 1958).

Von Wobeser, Gisela, Dominación Colonial. La consolidación de vales reales, 1804-1812 (México, Universidad Nacional Autónoma de México, 2003).

Misivas citadas:

Alvarez de Acevedo to Administrador General de la Real Renta de Tabacos, March 15 1778. Archivo General de Indias, Chile.

Álvarez de Acevedo to Navarro, March 13 $3^{\text {th }}, 1778$, Archivo General de Indias, Chile. Álvarez de Acevedo to Abaria, September $9^{\text {th }}$, 1778. Archivo General de Indias, Chile. Álvarez de Acevedo to Pedregal, January 28 ${ }^{\text {th }}, 1780$. Archivo General de Indias, Chile. Álvarez de Acevedo, Decree, April 2 ${ }^{\text {nd }}, 1781$. Archivo General de Indias, Chile, 328. Álvarez de Acevedo to José de Gálvez, June 1st, 1781. Archivo General de Indias, Chile, 418.

Álvarez de Acevedo to José de Gálvez, October 31st, 1781. Archivo General de Indias, Chile, 418.

AN, Capitanía General, Vol. 728.

Benavides to Gálvez, January 31'st, 1783. Archivo General de Indias, Chile, 192.

Echevers to Gálvez, January 29 ${ }^{\text {th }}$, 1777. Archivo General de Indias, Chile, 417.

Minister Gálvez to Álvarez de Acevedo, April 1st, 1779. AN, Capitanía General, 718. Navarro to Álvarez de Acevedo, March 13 ${ }^{\text {th }}, 1778$, Archivo General de Indias, Chile. Pedro Gálvez to José de Gálvez, September 6th, 1781. Archivo General de Indias, Chile, 418. 
Pedregal to Álvarez de Acevedo, Point 40, April 6 ${ }^{\text {th }}$, 1780. Archivo General de Indias, Chile.

Pedregal to Álvarez de Acevedo, Point 45, April 6 ${ }^{\text {th }}, 1780$. Archivo General de Indias, Chile.

Pedregal to Álvarez de Acevedo, Point 6, April 6 ${ }^{\text {th }}$, 1780. Archivo General de Indias, Chile.

President Jáuregui to José de Gálvez, December $3^{\text {rd }}$, 1781. Archivo General de Indias, Chile, 418.

May $20^{\text {th }}, 1782$. Archivo General de Indias, Chile, 328.

September $25^{\text {th }}, 1780$ (Auto signed by Álvarez de Acevedo). Archivo General de Indias, Chile.

November $7^{\text {th }}$, 1781. Archivo General de Indias, Chile, 328.

San Idelfonso, August 20 $0^{\text {th }}, 1778$. Archivo General de Indias, Chile, 328. 